\title{
Material culture at Allangkanangnge ri Latanete in relation to the origins of Bugis kingdoms
}

\author{
Budianto Hakim, Stuart Hawkins, David Bulbeck, lan Caldwell, \\ Stephen Druce and Campbell Macknight
}

\begin{abstract}
The early historical South Sulawesi site Allangkanangnge ri Latanete is reputed to be the location of the palace of the legendary Bugis kingdom of Cina. This vanished kingdom arose in the 13th century AD and disappeared in the 16th century. The Allangkanangnge ri Latanete site is dated to between the 13th and 17th centuries based on Carbon-14 determinations and imported stoneware and porcelain sherds recovered through survey and excavation. The material cultural remains excavated at the site are dominated by earthenware sherds: their frequencies indicate light occupation during the 13th century, a main period of habitation between the 14th and 16 th centuries, and a decline during the 17 th century. Excavated earthenware vessel forms reflect a range of functions including food preparation and storage. There is evidence of ironworking from iron slag debris, earthenware sherds identified as crucibles rims and local oral history. The excavated area near the summit of the hill is characterised by old Islamic graves, said to be those of the rulers of Cina. However, there is no evidence here for burials older than the 16th century; in earlier centuries, the area on the summit, which is protected by a low stone wall, may have been the location of a wooden palace. Some dozens of stone arrangements scattered over the eastern slope may possibly be associated with marking the burials of cremated remains in jars. The site displays a partially coastal orientation, both in terms of physical proximity and subsistence debris during the 13th and 14th centuries followed by a greater focus on wet-rice production during the 14 th to 17 th centuries.
\end{abstract}

Keywords: Allangkanangnge ri Latanete, Cina, Wajo, Bugis kingdoms, pre-Islamic history

\section{Introduction}

This article sets out a descriptive analysis of elite Bugis pre-Islamic material culture from the remains obtained through survey and excavation of the hilltop site of Allangkanangnge ri Latanete in the village of Sarapao, $6 \mathrm{~km}$ southeast of the regional capital of Sengkang in Wajo, South Sulawesi (Figure 17.1). This hilltop (hereafter, Allangkanangnge) is believed by local people to have been the palace site of Cina, one of the oldest kingdoms in South Sulawesi (Bulbeck and Caldwell 2000). Cina is also an important kingdom in the stories known as the La Galigo cycle. 
The date of these stories and the extent to which they reflect a memory of real events have been much debated (Pelras 1996; Nurhayati et al. 2003). The kingdom is rarely mentioned by name in Bugis chronicles, the sources of which date back to around 1400. Instead, the term 'Galigo' is used to refer to a period before the rise of the historical kingdoms.

Caldwell and Wellen (2017) have shown that Cina can be traced in genealogical sources from a group of three settlements in the western Cenrana Valley around 1300 to a peninsula-wide power in the 14th and 15th centuries. During the latter century, Cina founded at least two new palace centres at Baringeng in Soppeng and Amali in Bone. In the 16th century, Cina was attacked by Wajo, which seized its northern lands, and was later attacked in the east by Soppeng and in the south by Bone. By 1600, it had been dissolved and its ruling family vanquished, except for a branch in Luwu. As the origin story of Soppeng puts it, "Those whose ancestry could be traced to the age of Galigo were no more' (Caldwell 1988:109). It is clear from the 'Chronicle of Bone', however, that Cina was remembered by successor kingdoms as the source of political order and diplomacy. The chronicle states that 'the earlier kings who went back to Galigo had already organized [the conduct of] negotiations as well as of giving orders' (Caldwell and Wellen 2017:310).

Despite its apparent importance in the emergence of stratified society, it is difficult to envisage Cina as a centralised kingdom of the type familiar to 16th- and 17th-century European visitors. According to Bugis genealogies, Cina's lands stretched across the central peninsula, encompassing both lowland and highland areas, making it approximately the combined size of the three kingdoms-Wajo, Soppeng and Bone-that succeeded it (Figure 17.1). These kingdoms used highland areas as boundaries: La Ummasak, a mid to late 15th-century ruler of Bone, is recorded in the 'Chronicle of Bone' as having entered into treaties with hill chiefdoms instead of conquering them (Macknight and Mukhlis n.d.).

Only an echo of an apparently once powerful kingdom of Cina can be found in Bugis historical records. The most important source is a collection of nine related genealogies that record the relationships of a large elite group associated with Cina, and the names of places where they married and ruled. Other than these genealogies, there is little apart from an apocryphal tradition that Cina's name was changed to Pammana at the request of a late 16th-century ruler (Zainal Abidin 1983). Considering that the historical sources on Cina are almost all genealogical, it might be sensible to consider the kingdom of Cina as a reference to an extended, elite family that ruled at places across the central peninsula before about 1500 (Caldwell and Wellen 2017:316). ${ }^{1}$ The legitimising claim of this elite to rule was descent from an archetypal, heavenly ancestor (to manurung), Simpurusia, who descended at Lompo near Sengkang. Following this line of argument, 'Cina' is perhaps best interpreted as a metaphor for an age comprising the 13 th to 15 th centuries, as well as an actual kingdom of this name.

1 Caldwell (1988:171) sets out evidence that writing in the Bugis script was developed around 1400. Caldwell and Wellen (2016) have argued that for the first 200 years writing was used simply for recording elite genealogies, and perhaps the occasional treaty. 


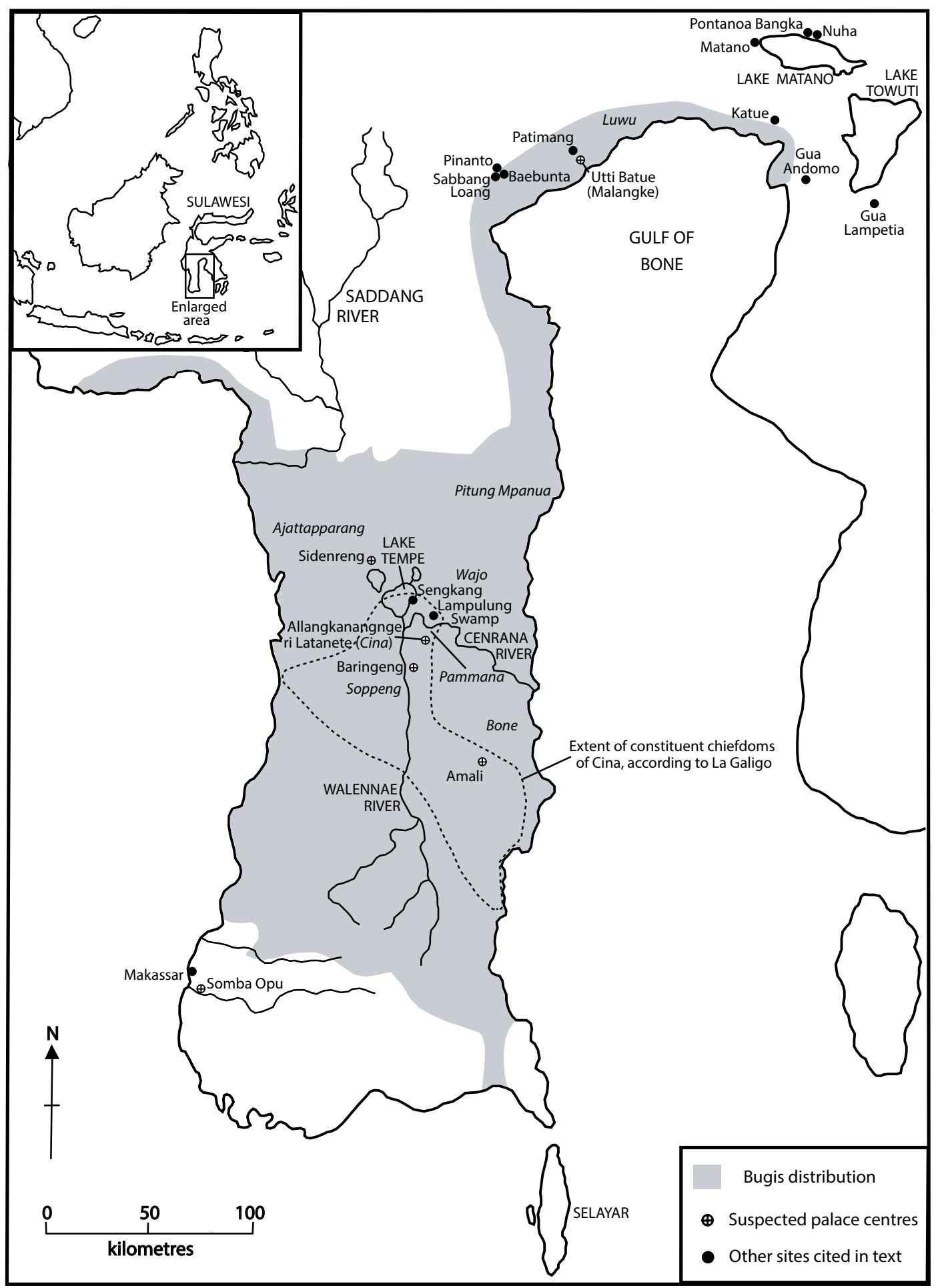

Figure 17.1: Southern Sulawesi with kingdoms and locations mentioned in the text.

Sources: Gremmen (1990); Bulbeck and Caldwell (2000); Bulbeck et al. (2016); Caldwell and Wellen (2017); Bulbeck et al. (this volume). 
This is not to deny that there may have been a powerful kingdom called Cina, the name of which became synonymous with the Bugis of the central peninsula. Agrarian kingdoms (or complex chiefdoms) first emerged in the Cenrana and Walennae valleys in the 13th century (Figure 17.1). ${ }^{2}$ Their rulers sponsored the expansion of wet-rice agriculture to produce a growing subsistence base and to extract a surplus for trade. The central role of wet-rice cultivation in these kingdoms' economies is clear from Bugis historical texts (Macknight 1983). Allangkanangnge's location in the western Cenrana valley, and the wealth of ceramics recovered from the summit, suggests that the hilltop was an early palace site occupied by members of an elite ruling family involved in this agricultural expansion. Ceramic sherdage from Allangkanangngne dates from the 13th century, and two 13th-century radiocarbon dates have also been obtained from the summit (Bulbeck et al., this volume). The hill itself is the largest in the chain of low hills that runs through Sengkang and southwards from the city (see Bulbeck 1992:Photo 1-2). These hills provide the natural points of control for trade and agriculture in the region south and west of Lake Tempe. It seems reasonable to hypothesise that Allangkanangnge may at one time have been a palace centre of a kingdom called Cina.

\section{The structure of Bugis historical agrarian kingdoms}

Bugis agrarian kingdoms were formed from groupings of wanua, the smallest Bugis political unit, which ranged in size from a single large settlement to a cluster of neighbouring settlements (Pelras 1996). A wanua could have under it several anaq banua (child wanua) while being at the same time subject to a more powerful wanua, making for a hierarchical confederation. Pelras (2010:233-234) argues that this was the basic system on which the Bugis kingdoms rested: 'All of them had been constituted around a core wanua (watang mpanua, 'trunk wanua') which, from the 15th century on, had progressively concluded treaties (uluada) with surrounding ones, henceforth called wanua paliliq ('satellite wanua').'

Wanua were headed by arung or chiefs, selected from a noble class whose members claimed descent in varying degrees from the rulers of the upper and lower worlds (Caldwell and Wellen 2016). Arung were embedded in networks of kin relations and obligations; power was executed though these networks, arranged and expressed as traditional allegiances. Large wanua groupings were structured around a primus inter pares, who, as arung of the central settlement, drew revenues from its lands, administered by matoa or district headmen. ${ }^{3}$ Above the level of headman, the Bugis political system was founded on a metaphysical claim to high status: arung were noble and had ancestors in the upper and lower worlds; matoa were commoners, and did not. The rulers of these kingdoms are recorded in historical sources as having encouraged and directed the expansion of wet-rice agriculture. They married their children to the children of tributary arung, and in times of conflict raised armies from tributary wanua. Treaty, marriage and war were the three key strategies used in the expansion of kingdoms.

By the 16th century, Bugis wanua groupings had grown to considerable size. The size and degree of centralisation of kingdoms varied according to geographic constraints. In some kingdoms, such as Bone, which lay on extensive agricultural lowlands, power was held by a ruler, advised by a small council of nobles. Kingdoms such as Wajo, which lay on a fragmented landscape of hills, valleys and marshlands, were less centralised. Wajo was led by an Arung Matoa ('lord headman'),

2 Contemporary written sources date back to about 1400, beyond which lie undatable oral traditions. The associated archaeological record stretches back a further century or two, in the form of imported Chinese and Southeast Asian ceramics (Bulbeck et al., this volume).

3 Rulers could hold lands in other areas of the kingdom and these appanages could be granted as fiefs.

\section{terira australis 48}


selected and advised by a council of 40 nobles. The office does not appear to have been easy: one Arung Matoa is recorded as having twice declined it, and for three years after his death the kingdom was ruled by his ashes (Zainal Abidin 1985:276).

Kingdoms, as well as smaller political units, could ally to form larger political groupings that allowed for corporate political decision-making. A well-known example is Ajattapparang, an alliance of five kingdoms northwest of Lake Sidenreng led by the ruler of Sidenreng (Druce 2009). An example of an alliance on a smaller scale is the Pitung Mpanua, a confederation of seven wanua on the northern borders of Wajo. Large or small, all political structures followed the same principles of alliance and hierarchy, and were headed by a recognised leader. As a result, it is not always easy to separate the idea of wanua groupings from those of kingdoms and alliances: the Bugis language has no single word for 'kingdom' or 'alliance', these terms reflect scholars' attempts to classify things by size and importance. An example of this problem is Lamuru, which formed part of Soppeng, and later Bone. Yet Lamuru had the structure of a kingdom, with an eponymous central place, appanage lands, tributary chiefdoms from which the ruler raised armies, and settlements or wanua groupings that were subject to these chiefs. The ruler of Lamuru held the title of Datu, as did the ruler of the Soppeng, as well as a number of his tributary chiefs, who were effectively heads of smaller wanua groupings. In short, the system was like a series of nesting boxes: the rulers of large kingdoms had tributary arung who were themselves rulers of smaller kingdoms who had tributary arung beneath them (Caldwell 1995).

\section{Site survey and excavation}

Allangkanangnge lies south of the Cenrana River, and east of the lower reaches of the Walennae River that drains the inland watershed of South Sulawesi's major cordilleras (Figure 17.1). ${ }^{4}$ The hill forms part of a low ridge that runs north-south through Sengkang. Geologically, this ridge, which separates the two watersheds, is composed of 'Celebes morasse' consisting of late Miocene to Pliocene conglomerate, sandstone, claystone and marl, interbedded with limestone and lignite (Sukamto 1975). The Allangkanangngne hill, which sits on the eastern side of the ridge, is currently uninhabited and planted with a variety of cash crops such as vegetables, tobacco, maize and cacao. The hill rises some $20 \mathrm{~m}$ above a shallow valley, the floor of which is laid out with wet-rice fields; the foot of the valley abuts the Cenrana River and floods when the river is high. Palynological records from Lampulung swamp, a short distance northeast of Allangkanangnge, indicate mangrove conditions at the head of the Cenrana as recently as 2600 years ago (Gremmen 1990). Until the 14th century, estuarine swamps lay within the foraging range of the Allangkanangnge's inhabitants, receding in later centuries as a result of the eastward progradation of the lower Cenrana (see below).

A survey of the summit of Allangkanangnge was carried out by a team funded by the Origin of Complex Society in South Sulawesi (OXIS) project ${ }^{5}$ in 1999 and a $1 \mathrm{~m} \times 1 \mathrm{~m}$ test pit was dug to approximately the 14th-century level (Bulbeck et al., this volume). Ali Fadillah, then director of the Makassar Archaeology Office, directed the 1999 survey and excavations, assisted by Ian Caldwell and Budianto Hakim. Allangkanangnge was surveyed again by an international team in 2005 directed by Ian Caldwell, Steven Druce and Campbell Macknight, when the site

\footnotetext{
4 In most years, the western and eastern cordilleras experience separate monsoonal events, approximately six months apart, resulting in two flooding events along the lower Walennae. The waters from the Walennae drain into the Cenrana River; as they rise they block the exit of the Bila River, which flows from the north. To meet the height of the swollen Walennae, the Bila River also has to rise, creating a floodplain called Lake Tempe (Caldwell and Lillie 2004).

5 The OXIS project was designed to combine archaeological data and local historical accounts in Luwu and along the Cenrana River for the purpose of investigating the roles of rice cultivation, iron metallurgy and organised trade as major economic factors in the establishment of the early Bugis kingdoms (Bulbeck and Caldwell 2000; Fadillah and Sumantri 2000).
} 
was divided into 41 zones including 19 where surface materials were collected (Figure 17.2). Collecting conditions were excellent as the hill had recently been cleared in preparation for the planting of cash crops. Zone 1, where the 2005 test pits were excavated (under Budianto Hakim's direction), is the reputed palace site of We Cudaiq, princess of Cina in the La Galigo stories. The zone is bounded by a $35 \mathrm{~m}$ x $30 \mathrm{~m}$ rectangular wall enclosing old Islamic graves. This wall contains the only stratified deposit on the site; outside this area, collected material lay directly on the surface, which may even have been slightly eroded.

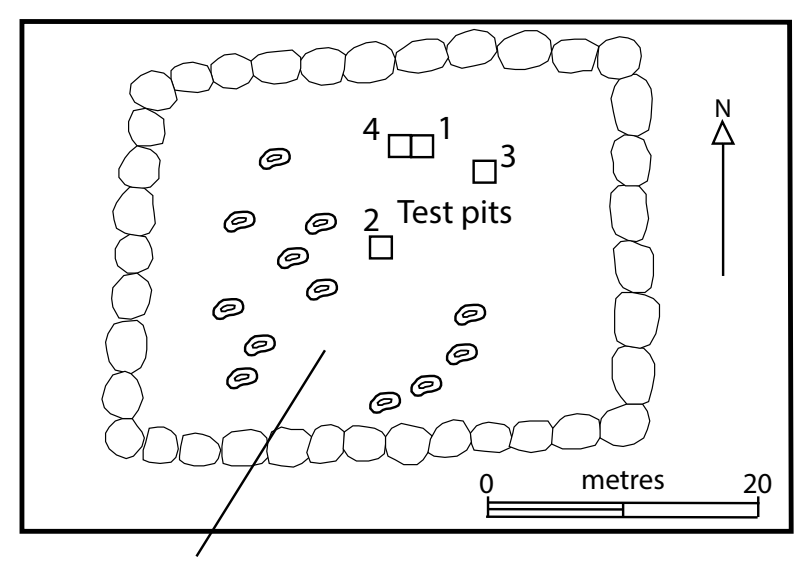

Zone 1 (enlarged)

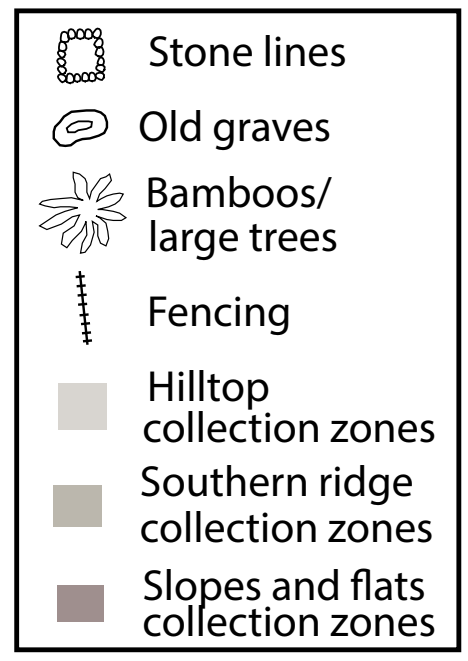

Legend

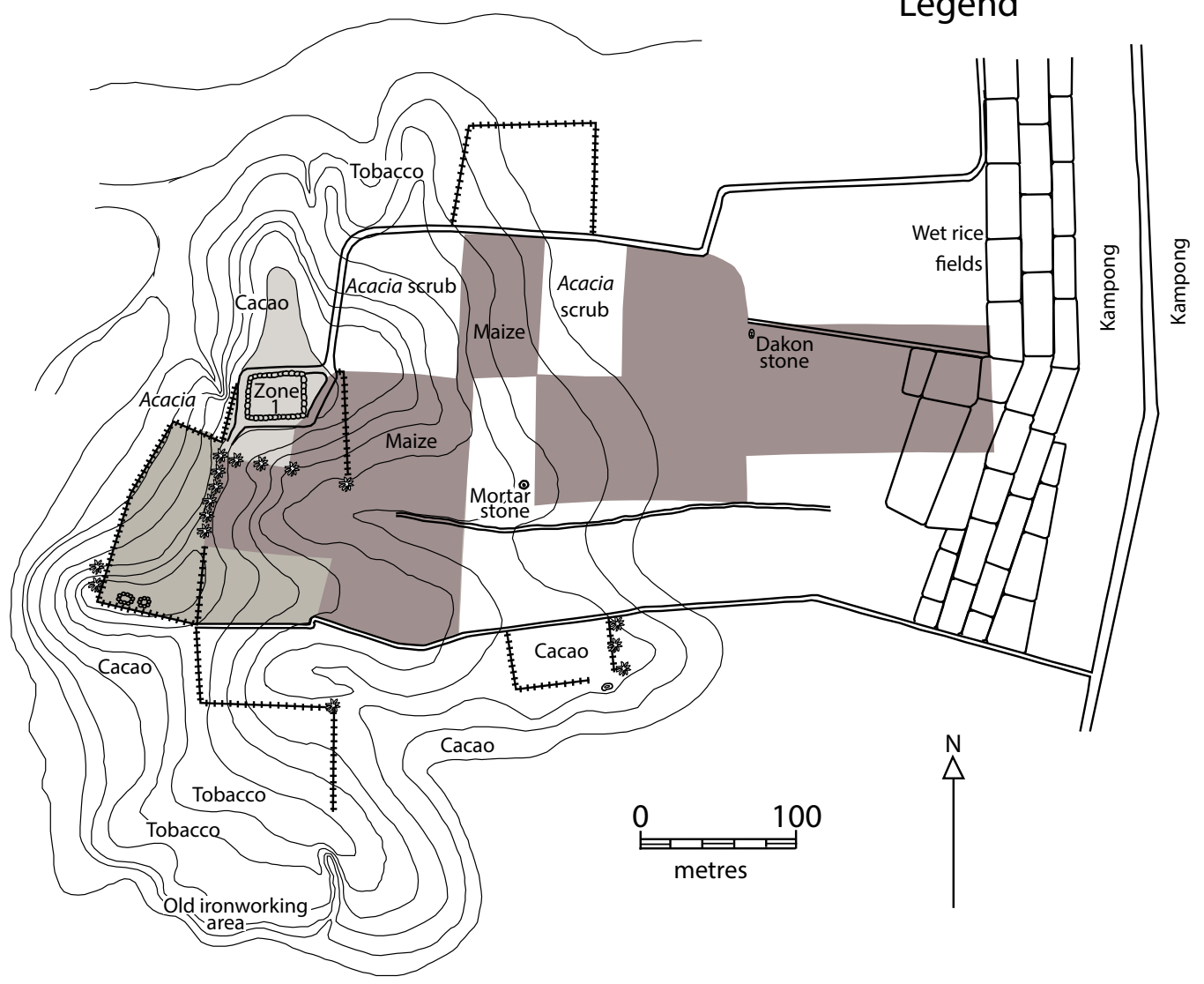

Figure 17.2: Theodolite survey of Allangkanangnge ri Latanete and grouped collection zones (2005). Source: Pak Mansur, Makassar Archaeology office. 
Other stone features include a mortar stone and dakon stone (with indentations for playing a game similar to Malay congklak) at the eastern corner, and two stone arrangements at the southwest corner. The latter are two of the best-preserved examples of the dozens of stone arrangements (most of which are now very disturbed) with a standing stone in their centre, often sculpted to show a rudimentary human head. Their main area of occurrence is the ridge line south of the summit, although other examples are distributed across the slopes to the east. Finally, Zone 20 (on the southern slopes) is locally known as Panré Bessié (Bugis for 'the iron smith') and is remembered as an old ironworking area.

A combined surface assemblage of 2120 tradeware sherds ${ }^{6}$ was collected by the current project during the 1999 and 2005 surveys. Around $95 \%$ of the sherdage is 13 th-17th century in age and reflects the occupation of the site from the 13th century to South Sulawesi's internecine wars of the mid-17th century. The remaining $5 \%$ of more recent sherdage relates to the site's subsequent use for dryland gardening, as well as the spiritual potency of the site, which attracts pilgrims to the site to this day (Bulbeck et al., this volume).

Four $1 \mathrm{~m}^{2}$ test pits (TP) were excavated, generally using spits of around $5-10 \mathrm{~cm}$ depth. TP1 was initially excavated in six spits to a depth of around $40 \mathrm{~cm}$ in 1999. The test pit was re-opened in 2005 and four further spits were excavated to sterile soil at a depth of $85 \mathrm{~cm}$. TP1 was placed near the north stone wall, TP2 near the centre of Zone 1, TP3 towards the east stone wall, and TP4 extended TP1 $1 \mathrm{~m}$ to the west. The other three pits were excavated down to sterile soil in 2005. TP4 revealed a $40 \mathrm{~cm}$ depression for a distinctive feature at the base into sterile soil, which was removed as a single unit. Apart from this feature, the stratigraphy of the test pits appeared generally featureless, although some layering could be observed when the sections were drawn. Plans were drawn at the completion of each spit and the location of any finds noticed by the excavators was plotted.

Sediment samples were not collected during the 2005 excavations, and we are unable to report on phytolith evidence from any of the spits excavated in 2005. We are, however, able to place the evidence for pre-Islamic rice processing at Allangkanangnge (Bulbeck and Caldwell 2008) in a more complete chronological and environmental context through the context of the 2005 excavations, and the five radiocarbon dates now available, all calibrated using Oxcal 4.2 (Bronk Ramsey 2016).

The stratigraphy in all of the test pits included deposit recorded during excavation as black silty sand in the upper spits and yellow silty sand in the lower spits. Topsoil development was also recorded for TP1, 2 and 3. The black sand contained the denser remains of habitation whereas the yellow sand extended between deposit, with light evidence for occupation higher up and sterile deposit at the base. This change in occupation debris would not appear related to preservation conditions because the alkalinity of the sediment, wherever tested, fell in the $\mathrm{pH}$ range of 7-7.5, which is neutral to slightly alkaline (Bulbeck 2000). TP4 was unusual in having a hole filled with black sand that plunged at an angle into the yellow sand and exited the western wall of the test pit as a feature encased by yellow sand. Stratigraphic sections of the test pits are presented in (Bulbeck et al., this volume).

\section{Excavated contents}

The main occupation phase in TP1 extends between Spits 1 and 7, which yielded more than 150 earthenware sherds per spit and all of the tradeware sherds excavated from this test pit (Table 17.1). With reference to the most recent of the tradeware sherds, Spits 1-3 would be dated to the 17th century, Spits 4-5 to the 16th century and Spits 6-7 to the 14th century. This last dating is confirmed by the Carbon-14 determination (ANU 11352) obtained from the marine

6 Identified by Karaeng Demmanari, a Makassar expert in tradewares, and David Bulbeck. 
(estuarine) shell sample from Spit 6, which is the stratigraphically highest marine shell sample in the test pit. Although the c. 14th-century dating for this sample is not secure, relying as it does on an estimate of the proportion of the 'marine reservoir effect' to allow for the delta $\mathrm{R}$ value to use in offsetting the date for the marine reservoir effect (footnote $d$ to Table 17.1), it is nonetheless consistent with the tradeware dating.

Table 17.1: Test pit 1 excavation summary.

\begin{tabular}{|c|c|c|c|c|c|c|c|c|c|}
\hline Spit & $\begin{array}{l}\text { Basal } \\
\text { depth }\end{array}$ & $\begin{array}{c}\text { Sediment } \\
\text { colour (wet) }{ }^{(\mathrm{a})}\end{array}$ & $\begin{array}{c}\text { Burnt } \\
\text { sediment }\end{array}$ & $\begin{array}{c}\text { Earthenware } \\
\text { sherds }\end{array}$ & $\begin{array}{l}\text { Imported } \\
\text { ceramics }^{(b)}\end{array}$ & other finds & $\begin{array}{c}\text { Vertebrate } \\
\text { fragments }(c)\end{array}$ & $\begin{array}{l}\text { Charcoal } \\
\text { (grams) }\end{array}$ & Shell \\
\hline 1 & $5-10 \mathrm{~cm}$ & Very dark grey & 2 grams & 361 & \begin{tabular}{|c|}
3 \\
(15th-17th \\
centuries)
\end{tabular} & $\begin{array}{l}\text { Iron rod, } \\
\text { bronze } \\
\text { fragment }\end{array}$ & $\begin{array}{c}52 \\
\text { (50 grams) }\end{array}$ & 1.5 & $\begin{array}{c}3 \text { fragments, } \\
2.0 \text { grams } \\
\text { (terrestrial) }\end{array}$ \\
\hline 2 & $10-15 \mathrm{~cm}$ & Very dark grey & 20 grams & 162 & $\begin{array}{c}3 \\
\text { (15th-16th } \\
\text { centuries) }\end{array}$ & - & $\begin{array}{c}22 \\
\text { (17 grams) }\end{array}$ & 7.6 & - \\
\hline 3 & $20-25 \mathrm{~cm}$ & Very dark grey & 18 grams & 718 & $\begin{array}{c}5 \\
\text { (15th-17th } \\
\text { centuries) } \\
\end{array}$ & $\begin{array}{c}\text { Glass bead } \\
\text { (0.2 grams) }\end{array}$ & $\begin{array}{c}79 \\
\text { (137 grams) }\end{array}$ & $\begin{array}{c}8.0(+ \\
0.1 \text { gram } \\
\text { wood) }\end{array}$ & - \\
\hline 4 & $25-30 \mathrm{~cm}$ & Very dark grey & - & 212 & $\begin{array}{c}6 \\
\text { (12th-16th } \\
\text { centuries) }\end{array}$ & - & 32 & 0.8 & - \\
\hline 5 & $30-35 \mathrm{~cm}$ & Very dark grey & - & 308 & $\begin{array}{c}5 \\
\text { (14th-16th } \\
\text { centuries) }\end{array}$ & - & 31 & 0.9 & - \\
\hline 6 & $38-43 \mathrm{~cm}$ & Very dark grey & - & 207 & $\begin{array}{c}2 \\
\text { (11th-14th } \\
\text { centuries) }\end{array}$ & - & 49 & 3.5 & $\begin{array}{c}3 \text { fragments, } \\
29.6 \\
\text { grams } \\
\end{array}$ \\
\hline 7 & $48-53 \mathrm{~cm}$ & Yellow & 5.1 grams & 512 & $\begin{array}{l}1 \text { (14th } \\
\text { century) }\end{array}$ & - & 88 & - & $\begin{array}{c}12 \\
\text { fragments, } \\
83.7 \\
\text { grams }^{(\mathrm{e})} \\
\end{array}$ \\
\hline 8 & $58-63 \mathrm{~cm}$ & Yellow & $\begin{array}{c}30.8 \\
\text { grams }\end{array}$ & 134 & - & $\begin{array}{l}2 \text { joining } \\
\text { iron } \\
\text { fragments }\end{array}$ & $\begin{array}{c}30 \\
\text { (89.6 grams) }\end{array}$ & $6.0(f)$ & $\begin{array}{c}21 \\
\text { fragments, } \\
15.0 \\
\text { grams(e) }\end{array}$ \\
\hline 9 & $68-74 \mathrm{~cm}$ & Yellow & $\begin{array}{c}40.4 \\
\text { grams }\end{array}$ & 53 & - & - & $\begin{array}{c}9 \\
\text { (42.4 grams) }\end{array}$ & $3.7(g)$ & $\begin{array}{c}4 \text { fragments, } \\
47.7 \\
\text { grams } \\
\text { (h) }\end{array}$ \\
\hline 10 & $85 \mathrm{~cm}$ & Yellow & - & - & - & - & - & - & - \\
\hline Total & - & - & 116 grams & 2,667 & 25 & - & 392 & 32.0 & $\begin{array}{c}70 \\
\text { fragments }\end{array}$ \\
\hline
\end{tabular}

(a) Munsell colour readings for Spits 1-6 (Bulbeck 2000); field descriptions for the lower spits.

(b) Summarised from Bulbeck et al. (this volume).

(c) Identifications in Makassar by David Bulbeck include two rodent teeth from Spit 4, a bovid molar from Spit 6 and a bovid proximal femur from Spit 7. In addition, 74 fragments from Spits 7-9 were sent to Canberra for specialist identification by Stuart Hawkins.

(d) Telescopium telescopium (estuarine), radiocarbon dated to 820+60 BP (ANU-11352), which calibrates to AD 1284-1449 (2 sigma), assuming 50\% marine content and delta R value of 89+70 (Sa Bui Bay, South Kalimantan).

(e) Telescopium telescopium (estuarine).

(f) Radiocarbon dated to 752+34 BP (Wk-17818), which calibrates to AD 1217-1289 (2 sigma).

(g) Radiocarbon dated as modern (Wk-17743), so the sample presumably resulted from contamination during the excavation.

(h) Telescopium telescopium (32.5 g), estuarine; Pinctada margaritifera (10.8 g), intertidal and subtidal; Saccostrea mytiloides (4.4 g), estuarine and intertidal. Pinctada margaritifera radiocarbon dated to 955+30 BP (Wk-19966), calibrates to AD 12131389 (2 sigma) assuming 50\% marine content and delta R value of 89+70 (Sa Bui Bay, South Kalimantan).

Source: Budianto Hakim and David Bulbeck's laboratory data. 
Early occupation of the site as reflected in TP1 (Spits 8-9) would appear to have been less intensive than during the main occupation phase (Table 17.1). Spit 8 is similar to Spit 2 (the sparsest of the spits from the main occupation phase) in its earthenware sherd count, vertebrate fragment count and charcoal quantity. Spit 9, which registers the evidence for initial occupation, is poorer than Spits 2 and 8 in all of these aspects. The distinguishing feature of Spit 9 is its evidence for the collection of intertidal and subtidal shellfish as well as estuarine shellfish. Chronometrically, the Spit 8 charcoal is securely dated to the 13th century, consistent with the 14th century and later datings for the stratigraphically higher spits, whereas the Spit 9 shellfish is estimated to date to the 13th or 14th century. In view of the uncertainties of Carbon-14 determinations on marine shellfish noted above, the most reasonable course would be to infer a 13th-century antiquity as indicated on stratigraphic grounds.

A notable feature of Spits 7-9 was their concentration of burnt sediment, which was absent from Spits 4-6 (Table 17.1). The surface of the burnt sediment from Spit 7 had in places a metallic sheen, suggesting the sediment derived from ironworking or other local metallurgical activities. The burnt sediment from Spit 8 contained very little charcoal, although it did contain comminuted shellfish fragments (around 3\% by weight), whereas the Spit 9 burnt sediment contained a greater density of carbon specks but no faunal material (David Bulbeck, laboratory notes, held privately). The Spit 7-9 samples may respectively represent the remnants of the surface, body and base of a hearth.

Only five spits were excavated in TP2 (Table 17.2), and the fifth spit was extended across just one quarter of the test pit because Hakim observed that its presence of habitation debris was minimal. Generally speaking, the density of habitation debris in TP2 was light throughout the sequence, as reflected by earthenware sherd and vertebrate fragment counts similar to or less than those recorded for Spit 9 in TP1. The marine shell from Spit 4, at the intersection between the upper black deposit and the lower yellow deposit, can be reasonably dated to the 13th-14th centuries (see below). Accordingly, there does appear to be an orderly stratigraphic sequence from c. 16th-century deposits at the top of TP2 to c. 13th-century deposits towards its base.

Table 17.2: Test pit 2 excavation summary.

\begin{tabular}{|c|c|c|c|c|c|c|}
\hline Spit & Basal depth & $\begin{array}{c}\text { Earthenware } \\
\text { sherds }\end{array}$ & $\begin{array}{l}\text { Imported } \\
\text { ceramics }^{(a)}\end{array}$ & $\begin{array}{l}\text { Vertebrate } \\
\text { fragments }\end{array}$ & $\begin{array}{l}\text { Charcoal } \\
\text { (grams) }\end{array}$ & Marine shell \\
\hline 1 & $10 \mathrm{~cm}$ & 60 & $\begin{array}{c}1 \\
\text { (16th century) }\end{array}$ & 2 & - & - \\
\hline 2 & $20 \mathrm{~cm}$ & 59 & - & 6 & - & - \\
\hline 3 & $40 \mathrm{~cm}$ & 7 & - & - & - & - \\
\hline 4 & $60 \mathrm{~cm}$ & 15 & - & - & 1 & 4 (20 grams) $^{(b)}$ \\
\hline 5 & $85 \mathrm{~cm}$ & 1 & - & 1 & - & - \\
\hline Total & - & 142 & 1 & 9 & 1 & 4 fragments \\
\hline
\end{tabular}

(a) Bulbeck et al. (this volume).

(b) One fragment each of Telescopium telescopium (estuarine), Anadara (intertidal), Terebralia sulcata (mangroves) and Ostreidae. Source: Budianto Hakim and David Bulbeck's laboratory data.

The black deposit in TP3 extended from Spit 1 to Spit 4, where it interfaced with the underlying yellow deposit. Tradeware sherds were recovered from the upper spits and their datings suggest an orderly chronological sequence from c. 16th-century antiquity in Spit 1 to c. 14th-century antiquity in Spit 3 (Table 17.3). Unfortunately, the black layer in TP3 was notably disturbed, as recorded by the excavators, which would appear to account for how 13th-14th-century marine shellfish (see below) could have been recovered from every spit below Spit 1 . Nonetheless, a substantial assemblage of earthenware pottery was recovered from Spits 2 and 3, even if its chronological status can be no more precisely described than probably predating the 16th century. 
Table 17.3: Test pit 3 excavation summary.

\begin{tabular}{|l|c|c|c|c|c|c|}
\hline Spit & Basal depth & $\begin{array}{c}\text { Earthenware } \\
\text { sherds }\end{array}$ & $\begin{array}{c}\text { Imported } \\
\text { ceramics }^{(\mathrm{a})}\end{array}$ & $\begin{array}{c}\text { Vertebrate } \\
\text { fragments }^{(\mathrm{b})}\end{array}$ & Charcoal $^{\text {Marine shell(c) }}$ \\
\hline 1 & $5 \mathrm{~cm}$ & 20 & $\begin{array}{c}4\left(15 \text { th-17th }^{(\mathrm{c}}\right. \\
\text { (enturies) }\end{array}$ & 6 & - & - \\
\hline 2 & $15 \mathrm{~cm}$ & 212 & $\begin{array}{c}1(15 \text { th } \\
\text { (entury) }\end{array}$ & 16 & 3 grams & 4 fragments \\
\hline 3 & $35 \mathrm{~cm}$ & 499 & $\begin{array}{c}3(12 \text { th-15th } \\
\text { (enturies) }\end{array}$ & 62 & Wood fragment & 8 fragments \\
\hline 4 & $45 \mathrm{~cm}$ & 23 & - & 2 & 3 grams & 3 fragments \\
\hline $5^{(\mathrm{d})}$ & $60 \mathrm{~cm}$ & 16 & - & 1 & - & 2 fragments \\
\hline Total & - & 770 & 8 & 87 & 6 grams & 17 fragments \\
\hline
\end{tabular}

(a) Summarised from Bulbeck et al. (this volume).

(b) Identifications in Makassar by David Bulbeck include a bovid molar from each of Spit 1 and Spit 3 and a bovid incisor from Spit 3.

(c) Collection includes 12 fragments of Telescopium telescopium (estuarine), three fragments of Veneridae (marine), and one fragment each of Anadara (intertidal) and Pinctada margaritifera (intertidal/subtidal).

(d) Finds restricted to upper part of spit.

Source: Budianto Hakim and David Bulbeck's laboratory data.

TP4, which abuts TP1, produced a similar concentration of habitation debris to TP1 in Spits 1-4 (Table 17.4). In Spit 5, the deposit was observed to be sterile across most of the square, but Hakim noted a dark feature plunging into the sterile yellow deposit in the southwest corner. Excavation of the feature (Spit 6) yielded iron slag along with charcoal of more than $200 \mathrm{~g}$. A sample of $20 \mathrm{~g}$ was dated, yielding a calibrated age of AD 1450-1633.

Table 17.4: Test pit 4 excavation summary.

\begin{tabular}{|l|c|c|c|c|c|c|c|}
\hline Spit & $\begin{array}{c}\text { Basal } \\
\text { depth }\end{array}$ & $\begin{array}{c}\text { Earthenware } \\
\text { sherds }\end{array}$ & $\begin{array}{c}\text { Imported } \\
\text { ceramics(a) }\end{array}$ & Other finds & $\begin{array}{c}\text { Vertebrate } \\
\text { fragments }\end{array}$ & $\begin{array}{c}\text { Charcoal } \\
\text { (grams) }\end{array}$ & $\begin{array}{c}\text { Shellfish } \\
\text { fragments }\end{array}$ \\
\hline 1 & $15 \mathrm{~cm}$ & 190 & - & - & 7 & - & - \\
\hline 2 & $25 \mathrm{~cm}$ & 255 & $\begin{array}{c}1(15 \text { th-16th } \\
\text { (enturies) }\end{array}$ & - & 32 & 16 & - \\
\hline 3 & $35 \mathrm{~cm}$ & 74 & $\begin{array}{c}2(15 \text { th-16th } \\
\text { centuries) }\end{array}$ & - & $10(207.5 \mathrm{~g})$ & 10 & $3(20.4 \mathrm{~g})^{(\mathrm{c})}$ \\
\hline 4 & $45 \mathrm{~cm}$ & 282 & - & - & $26(175.6 \mathrm{~g})$ & 15 & $8(70.6 \mathrm{~g})^{(\mathrm{d})}$ \\
\hline 5 & $55 \mathrm{~cm}$ & 37 & $\begin{array}{c}1(16 \text { th-17th } \\
\text { centuries) }\end{array}$ & - & $11(144.2 \mathrm{~g})$ & - & $11(64.0 \mathrm{~g})^{(\mathrm{e})}$ \\
\hline 6 & $95 \mathrm{~cm}$ & 30 & - & Iron slag & $11(48.3 \mathrm{~g})$ & $207^{(\mathrm{f})}$ & $4(27.5 \mathrm{~g})^{(\mathrm{g})}$ \\
\hline Total & - & 868 & 4 & - & 97 fragments & 248 & 26 fragments \\
\hline
\end{tabular}

(a) Summarised from Bulbeck et al. (this volume).

(b) Identifications in Makassar by David Bulbeck include a bovid molar from Spit 2 and six pig molars from Spits 3-5. In addition, 58 fragments from Spits 3-6 were sent to Canberra for specialist identification by Stuart Hawkins.

(c) Telescopium telescopium (9.4 g) (estuarine); Anadara granosa (1.6 g) (intertidal).

(d) Telescopium telescopium (49.8 g) (estuarine); Polymesoda coaxans (12.4 g) and Terebralia sulcata (8.4 g) (mangroves).

(e) Telescopium telescopium (58.0 g) (estuarine); Batissa violacea (3.4 g) (coastal streams); Anadara sp. (2.0 g) (intertidal); Ostreidae (0.6 g).

(f) Radiocarbon dated to $364 \pm 25$ BP (Wk-29737), which calibrates to AD 1450-1633 (2 sigma).

(g) Telescopium telescopium (25.4 g) (estuarine); Batissa violacea (2.1 g) (coastal streams).

Source: Budianto Hakim and David Bulbeck's laboratory data. 
This basal date is inconsistent with the probable 13th-14th-century antiquity of the marine shellfish recovered from Spits 3-5 as well as Spit 6 (see below). The presence of a crucible fragment (Table 17.5 below) together with iron slag in the TP4 Spit 6 feature suggests that they were redeposited in the feature from higher in the profile when a hole was dug deep into sterile deposit. However, this would not explain the much larger concentration of charcoal in Spit 6 compared with the higher spits. Accordingly, this charcoal is inferred to represent the remains of a cremation burial, the traditional burial mode amongst the Bugis in pre-Islamic times (Druce et al. 2005). This interpretation would explain the large amount of charcoal in this sample compared to elsewhere in the site, and its relatively young age of AD 1450-1633 (barely within the pre-Islamic period) relative to its depth.

\section{Description of the inorganic excavated remains}

\section{High-fired ceramics and glass beads}

The small excavated assemblage of high-fired ceramics and the large surface assemblage are similar in predominantly dating to the same 13 th-17th-century time frame. Compared with tradeware assemblages from other Bugis sites, the remarkable features of the Allangkanangnge tradewares are their high frequencies of large martavan jars (about half of the sherdage) including Jizhou iron-painted wares, and early (13th-14th century) whitewares, coupled with a relatively low concentration of 16th-century Chinese blue-and-white sherds. In particular, the tradeware assemblage from the Allangkanangnge hilltop collection zones (Figure 17.2) is distinguished from the assemblage from the site's slopes and flats by having a higher proportion of Jizhou and other martavan sherdage, as well as a larger proportion of the older ceramic categories (13th14 th centuries, compared to the 15 th -17 th centuries). The tradeware assemblage from the southern ridge, where the rectangular stone arrangements are concentrated, resembles the hilltop assemblage in its high proportion of martavan sherds, but not in the antiquity of the sherdage, which instead resembles the slopes and flats assemblage. In summary, while imported ceramics of all types and all ages were found widely distributed across the site, martavans (mainly from production centres in China and Vietnam) and older ceramic classes were most concentrated on the hilltop (Bulbeck et al., this volume).

The glass bead from Spit 3 of TP1 is oblate in Horace Beck's (1936) terminology. It is of moderate size with a length of $6.6 \mathrm{~mm}$, maximum diameter of $7.6 \mathrm{~mm}$, and stringing-hole diameter of $2.1 \mathrm{~mm}$. The colour is dark greenish-grey (Munsell 5GY 4/1). The size, shape and colour fall comfortably within the range recorded for late 2 nd millennium AD glass beads excavated from Gua Andomo and Gua Lampetia in southeastern Sulawesi (Bulbeck et al. 2016). However, the single glass bead from Allangkanangnge, compared with its excavated earthenware count of 4447 sherds (Tables 17.1-4), contrasts with the much higher number of 283 glass beads from Gua Andomo and Gua Lampetia and their much lower number of 1066 earthenware sherds $(19.35 \mathrm{~kg})$. Instead, Allangkanangnge is similar to the 15th-16th-century Bugis suspected palace centre of Utti Batue in Luwu, where a single glass bead (weighing $0.1 \mathrm{~g}$ ) was excavated in association with a large earthenware assemblage of nearly $20 \mathrm{~kg}$ (Bulbeck et al. 2007). This comparison suggests that glass beads constituted a minimal component of the material culture at Bugis palace centres, in contrast with their importance for adornment and as status symbols in other parts of Indonesia such as Kalimantan, Nusa Tenggara and West Papua until ethnographic times (Adhyatman and Arifin 1996:3). 


\section{Metallic remains}

The only available documentation on the iron rod and bronze fragment from Spit 1 in TP1 is their collective weight of $4 \mathrm{~g}$. The two iron fragments from Spit 8 in TP1 together constitute what may be the terminal blade and tip of a knife or dagger. The blade is wavy and the tip is offcentre, suggesting this may have been part of a keris dagger. Their weight, including the corrosion product, is $11.3 \mathrm{~g}$; combined length is $60 \mathrm{~mm}$, and the blade inside the corrosion product would have had a maximum width of $18 \mathrm{~mm}$ and maximum thickness of $6 \mathrm{~mm}$. The iron slag from the Spit 6 feature in TP4 is a small, amorphous fragment weighing $8 \mathrm{~g}$ and coloured dark grey.

Evidence for iron metallurgy in South Sulawesi dates back to the 1st millennium AD in Luwu, in the form of small quantities of iron slag/gangue from Katue and Sabbang Loang, and abundant ironstone at Pontanoa Bangka (Bulbeck and Caldwell 2000; Do 2013). This was followed by the establishment of industrial sites for smelting the local iron ore fortified with nickel and especially chromium at the Lake Matano sites of Nuha (11th-13th centuries) and Matano (15th-18th centuries) (Do 2013). Evidence for local ironworking (iron slag, ironstone) is a regular feature of Luwu sites dating to approximately the 16th century, including Pinanto (Do 2013), Baebunta, Pattimang (Bulbeck and Prasetyo 2000) and Utti Batue (Bulbeck et al. 2007). South of Luwu, oxidised iron fragments have frequently been recovered from the excavation of open-air sites (e.g. Nayati 2005), but the 16th-17th-century fortified palace of Somba Opu is one of the few sites where the excavators felt confident in identifying iron slag (Tim 1992:59).

The salience of the kingdom of Luwu until the early 17 th century is attributed to its export of high-quality iron weapons and tools prior to the widespread availability of imported steel by the 18th century, which led to a proliferation of local iron-puddling workshops (Bulbeck and Caldwell 2000; Do 2013). The excavated, pre-Islamic samples from Allangkanangnge provide the opportunity for future chemical testing for a 'Luwu signature'.

\section{Earthenware pottery}

The earthenware pottery was analysed by Budianto Hakim. It accounts for the bulk of the excavated material from Allangkanangnge, similar to the situation at Uttie Batue where earthenware pottery also accounted for the bulk of the inorganic remains. The 4447 excavated earthenware sherds at Allangkanangnge dwarfs the 38 excavated tradeware sherds (Tables 17.117.4), producing a ratio of approximately $1: 120$, which resembles the excavated tradeware/ earthenware (by weight) of approximately 1:50 at Utti Batue (Bulbeck et al. 2007). A relatively small number of earthenware sherds (not covered in this contribution) were also collected from the surface of Allangkanangnge, consisting of visibly decorated sherds and/or sherds with a rim or base.

By dint of its abundance, compared with the other classes of excavated finds, earthenware pottery may be the most reliable indicator of occupation intensity. On that basis, the small earthenware assemblage in TP1 assignable to the 13th century (Spits 8 and 9), compared with the 14th17th-century spits, would point to light occupation prior to the 14th century (Table 17.1). As for the TP1 spits for which excavated sediment weights were recorded (Bulbeck and Caldwell 2008:Table 17.2), these suggest more intensive occupation in Spits 5-6 (14th-16th centuries) than the overlying spits (16th-17th centuries). Similarly, the TP3 earthenware counts suggest a reduced occupation intensity after the 15 th century (Tables 17.3). ${ }^{7}$

7 TP2 and TP4 (Tables 17.2 and 17.4) appear to reflect occupation intensity during the 16th and 17 th centuries at a similar level to the 15th century, but their excavated contents are respectively slight and disturbed. 
Most of the Allangkanangnge earthenware appears to represent a single fabric type, described as coarse and variable in its density, and with Munsell hues ranging between 2.5YR and 10YR (predominantly brown, reddish-brown and greyish-brown). Five sherds in TP1 and three sherds in TP4 stood apart from the rest of the assemblage. Two sherds (TP1 Spit 3) resemble kaolin-rich fine 'white pottery' found at scattered early historical trading sites across Indonesia, Malaysia and the Philippines (Miksic and Yap 1990; Stargardt 2003). Three sherds from TP1 Spits 2 and 3 were identified from their appearance as resembling Luwu 'soft pottery' of 14th-17th-century age (Bulbeck 2009), which corroborates the close links between pre-Islamic Cina and Luwu as indicated by textual evidence (Caldwell and Wellen 2017). Three sherds from Spit 4 of TP 4 appeared to be unusually high-fired, with the toughness of stoneware; two of them have red walls and a black core, while the third, possibly a cover, has an unusual shape.

Pottery decorations recorded in Spits 7-9 of the TP1 assemblage, and from the other test pits, are similar to those illustrated in Bulbeck and Caldwell (2008) for TP1 Spits 1-6, consisting predominantly of criss-cross paddle impressions, and otherwise horizontal incisions and punctate lines of dots. Approximately $8 \%$ of the studied sherds are decorated (Bulbeck and Caldwell 2008), notably higher than at Utti Batue where a very small number of decorated sherds (with motifs generally different from those at Allangkanangnge) were recorded (Bulbeck et al. 2007). On the other hand, the limited range of motifs at both of these sites suggests this may be a feature of Bugis historical sites, apparently contrasting with historical sites near Makassar with their wide variety of decorations on the pottery collected from surface contexts (Clune and Bulbeck 1999).

Just over 800 earthenware forms at Allangkanangnge could be identified on the basis of sherds that retain diagnostic sections such as rims or feet (Table 17.5; Figure 17.3). The most commonly identified form was standard bowls (Indonesian, mangkuk), making up $34 \%$ of the identifications, and identified in most of the spits. The other relatively common forms, together accounting for $46 \%$ of the identifications, included large bowls (jambangan), large pots (pasu) and cooking pots (periuk). Small numbers of sherds were identified as representing earthenware cooking stoves (tungku), large jars (tempayan and buyung), covers (tutup), censers (pedupaan) and small serving vessels (cups or cangkir and a suspected jarlet or buli-buli).

Large jars were restricted to TP1, suggesting a storage function not represented at the other test pits. This aligns with the phytolith evidence for processing and storing rice recovered in abundance from Spits 1-6 in TP1 (Bulbeck and Caldwell 2008). Nonetheless, the earthenware identifications from all four test pits suggest that a range of domestic tasks, including cooking and serving food, had been undertaken across the site.

Possibly the most interesting earthenware form is the crucible (Indonesian, wadah pelebur logam) because its identification corroborates oral memories that ironworking formerly occurred at the site. Of particular note is a concentration of 34 crucible fragments in Spits 7-9 of TP1, which accords with the metallic sheen noted on the sediment sample from Spit 8 in suggesting that a portion of the sediment consists of metalworking debris. A second concentration involves the 17 crucible fragments from TP4, although with 16 of them recovered from above the iron slag in Spit 6. 


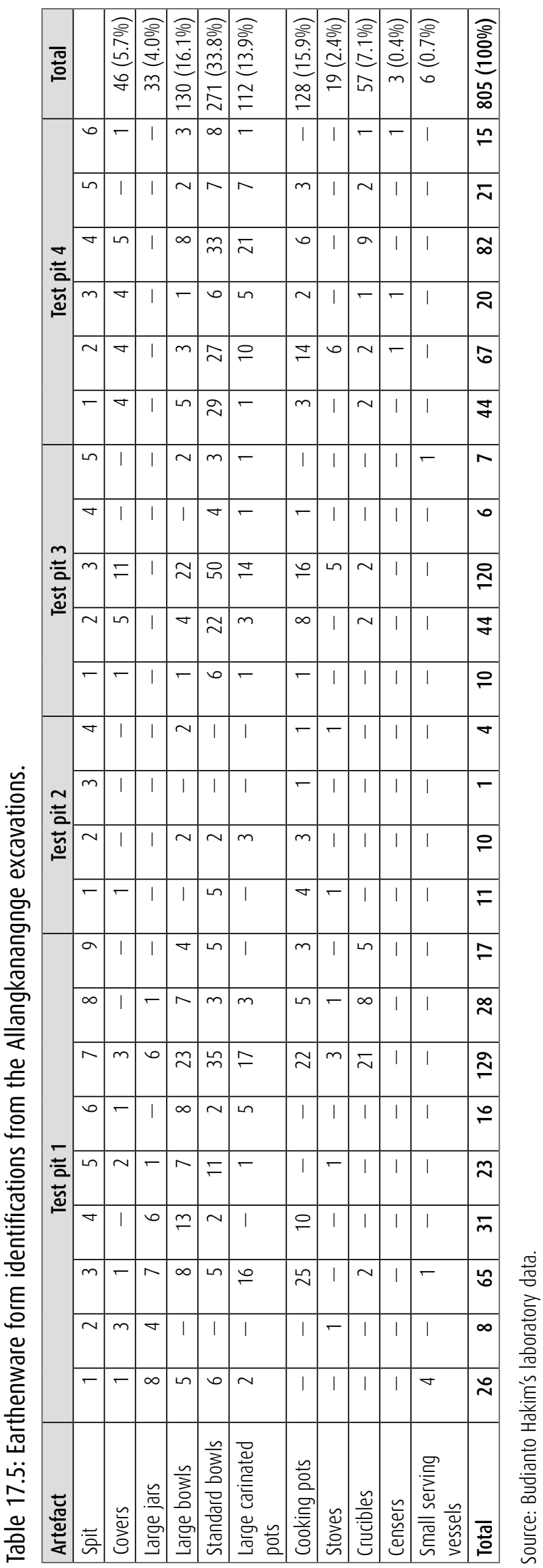




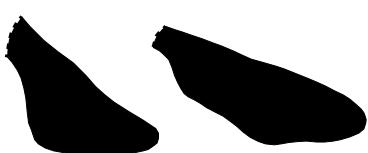

Cover rims TP3 spit 2
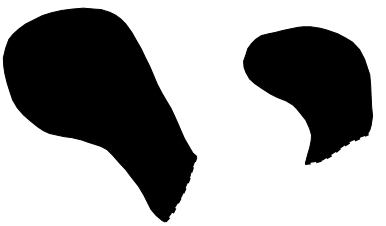

Tempayan large jar rims TP1 spit 4 (left) and TP1 spit 3 (right)
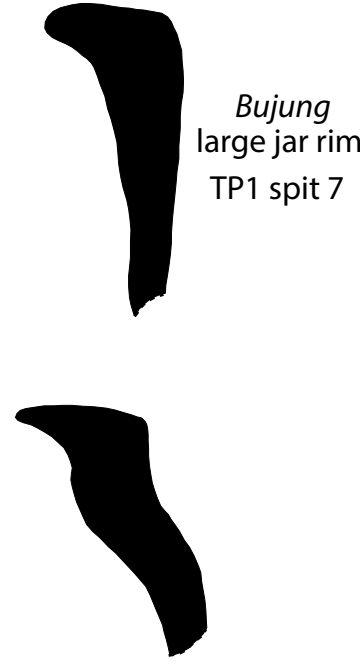

Standard bowl rims

TP1 spit 3 (left) and TP1 spit 7 (right)
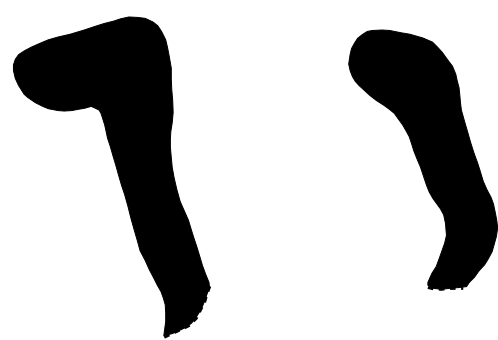

Cooking pot rims

TP1 spit 4 (left) and TP2 spit 4 (right)

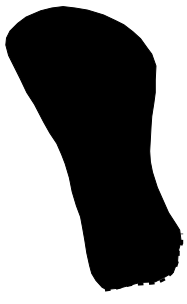

Stove rim TP4 spit 2
Large pot rim

TP3 spit 3

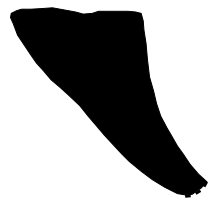

.
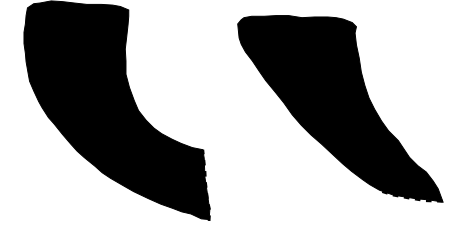

Crucible rims

TP4 spit 4

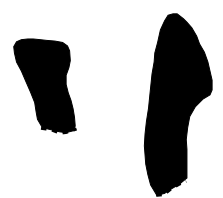

Cup rims TP1 spit 1

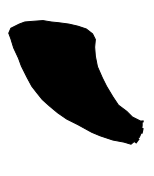




\section{Description of the organic excavated remains}

\section{Shellfish remains}

The shellfish were identified by Budianto Hakim and David Bulbeck with reference to an identikit based on complete and semi-complete specimens collected from sites excavated in 1998 and 1999 in Luwu (see Bulbeck and Caldwell 2000). These specimens were sent in 1999 to Ian Loch, then curator of the Malacology Collection at the Australian Museum, who provided identifications to the species or, occasionally, just the genus level. There are two sets of the shell identikit, one in Makassar and one at The Australian National University, and both were used in identifying the Allangkanangnge mollusc remains.

The main collected taxon was Telescopium telescopium, an estuarine species, which was represented in every spit with shellfish and accounted for about $80 \%$ of the total assemblage (Tables 17.1-17.4). Except for Spits 6-8 in TP1, the shellfish collections also contained other taxa, all represented in small quantities of about $15 \mathrm{~g}$ or less. These include the mangrove species Terebralia sulcata (Belitong snail) and Polymesoda coaxans (mud mussel), the estuarine/intertidal Saccostrea mytiloides (tropical black-lipped rock oyster) along with other Ostreidae, the intertidaldwelling Anadara granosa (ark clam), the intertidal/subtidal Pinctada margaritifera (black-lipped pearl oyster), marine Veneridae (Venus clams), and Batissa violacea, which is a freshwater clam found in coastal streams. B. violacea looks out of place in its association with a less brackish hydrology than T. telescopium, whereas the other taxa are associated with a mangrove or intertidal environment.

The TP1 sequence, which can be considered the site's 'master sequence', suggests a transition from collecting of both estuarine and intertidal shellfish associated with Spit 9, to purely estuarine collecting of T. telescopium associated with Spits 6-8. Direct radiocarbon dates (Table 17.1) suggest a c. 13th-century date for the Spit 9 shellfish and a c. 14th-century date for the Spit 6 shellfish, providing a time frame for this transition. Such a transition is not evident for the other test pits where T. telescopium was consistently associated with mangrove or intertidal species (Tables 17.2-17.4), which would recommend a generalised 13th/14th-century dating for these assemblages. In the case of TP2, all of the shellfish were found in a single spit low in the habitation sequence; in the case of TP3, the shellfish were recovered from deposits noted by the excavators to be disturbed. Disturbance, indeed a partially inverted stratigraphy, is particularly evident for TP4 in view of the recovery of the site's only freshwater shellfish from the two basal spits of TP4, as also reflected in the ceramic datings (Bulbeck et al., this volume).

\section{Vertebrate remains}

A total of 132 vertebrate specimens excavated from Spits 7-9 of TP1 $(176.1 \mathrm{~g})$ and Spits 3-6 of TP4 (575.6 g) were sent to The Australian National University for specialist analysis by Stuart Hawkins. Most identifications were made by comparison with the Archaeology and Natural History osteological reference collection. Two suspected Anoa (pygmy water buffalo) fragments were taken to Paris to check the identification at the Comparative Anatomy Collection at France's National Museum of Natural History (in one case, disproving the suspected identification). The TP1 assemblage is of particular interest in being dated to the period of shellfish foraging during the 13th/14th centuries, whereas the TP4 assemblage unfortunately cannot be dated more closely than to the 13 th/14th-16th/17th-century period of main site occupancy. 
Only $3 \%$ of the faunal remains consisted of complete bones (all foot bones); the rest were highly fragmented. Identifications were made to the lowest taxonomic level possible: family, genus or species (Tables 17.6 and 17.7). But in many cases, depending on the degree of how fragmented and diagnostic a bone was, this could only be narrowed down to sheep/goat, large/medium bovine or even broader and less specific identifications to large/medium mammal, mammal or fish. In some instances, tentative identifications have the prefix cf., which means compare, and this represents a close match. The bones are quantified by Number of Individual Specimens (NISP), but, in some cases, it could be established that more than one Minimum Number of Individuals (MNI) was present. Ages were estimated into juvenile, sub-adult and adult categories based on rates of known epiphyseal fusion for domesticated mammals (Silver 1969; Schmid 1972; Wilson et al. 1982) to understand animal exploitation strategies.

Table 17.6: Allangkanangnge taxa NISP by provenance.

\begin{tabular}{|c|c|c|c|c|c|c|c|c|}
\hline \multirow[b]{2}{*}{ Taxon } & \multicolumn{4}{|c|}{ TP4 spits } & \multicolumn{3}{|c|}{ TP1 spits } & \multirow[b]{2}{*}{ Total } \\
\hline & 3 & 4 & 5 & 6 & 7 & 8 & 9 & \\
\hline Bubalus depressicornis & 1 & 0 & 0 & 0 & 0 & 0 & 0 & 1 \\
\hline Bubalus bubalis & 3 & 3 & 2 & 4 & 0 & 1 & 1 & 14 \\
\hline Medium bovine & 0 & 0 & 0 & 0 & 0 & 3 & 0 & 3 \\
\hline cf. Capra hircus & 1 & 0 & 1 & 0 & 3 & 0 & 0 & 5 \\
\hline Suidae & 0 & 2 & 1 & 0 & 0 & 0 & 3 & 6 \\
\hline Canis cf. familiaris & 1 & 0 & 0 & 0 & 0 & 0 & 1 & 2 \\
\hline Rattus sp. & 0 & 0 & 0 & 0 & 1 & 0 & 0 & 1 \\
\hline Medium mammal & 4 & 2 & 1 & 2 & 2 & 2 & 2 & 15 \\
\hline Large mammal & 0 & 0 & 0 & 0 & 0 & 1 & 1 & 2 \\
\hline Mammal & 0 & 19 & 6 & 5 & 18 & 21 & 0 & 69 \\
\hline Testudines & 0 & 0 & 0 & 0 & 11 & 0 & 0 & 11 \\
\hline Fish & 0 & 0 & 0 & 0 & 0 & 2 & 0 & 2 \\
\hline Bird & 0 & 0 & 0 & 0 & 0 & 0 & 1 & 1 \\
\hline Total & 10 & 26 & 11 & 11 & 35 & 30 & 9 & 132 \\
\hline
\end{tabular}

Source: Stuart Hawkins' laboratory data.

Bone modifications were recorded including the number of cut marks and their location on the bone, as well as the bone fracture orientation and fracture surfaces according to Sadek-Kooros (1975). The animal remains show signs of intensive butchery with $9.9 \%$ of bones displaying cut marks, with several observed parallel cut marks (13 bones with a total of 32 cut marks) indicating intensive meat removal; $9.9 \%$ of bones had observed oblique regular fractures, $5.3 \%$ observed transverse regular fractures, while $42.4 \%$ of the assemblage consists of small bone fragments with fresh breaks of no discernible orientation. Five long bones had regular longitudinal fractures split down the shaft, an indication that bones were split for marrow extraction, while oblique and transverse regular fractures have been associated with human butchery practices (Sadek-Kooros 1975; Shipman et al. 1981; Morales Muniz 1988). A few bones show signs of post-deposition mechanical breakdown, with $3 \%$ of bones with transverse irregular breaks, $13.8 \%$ of bones with stepped fractures and $2.3 \%$ with oblique irregular breaks. 


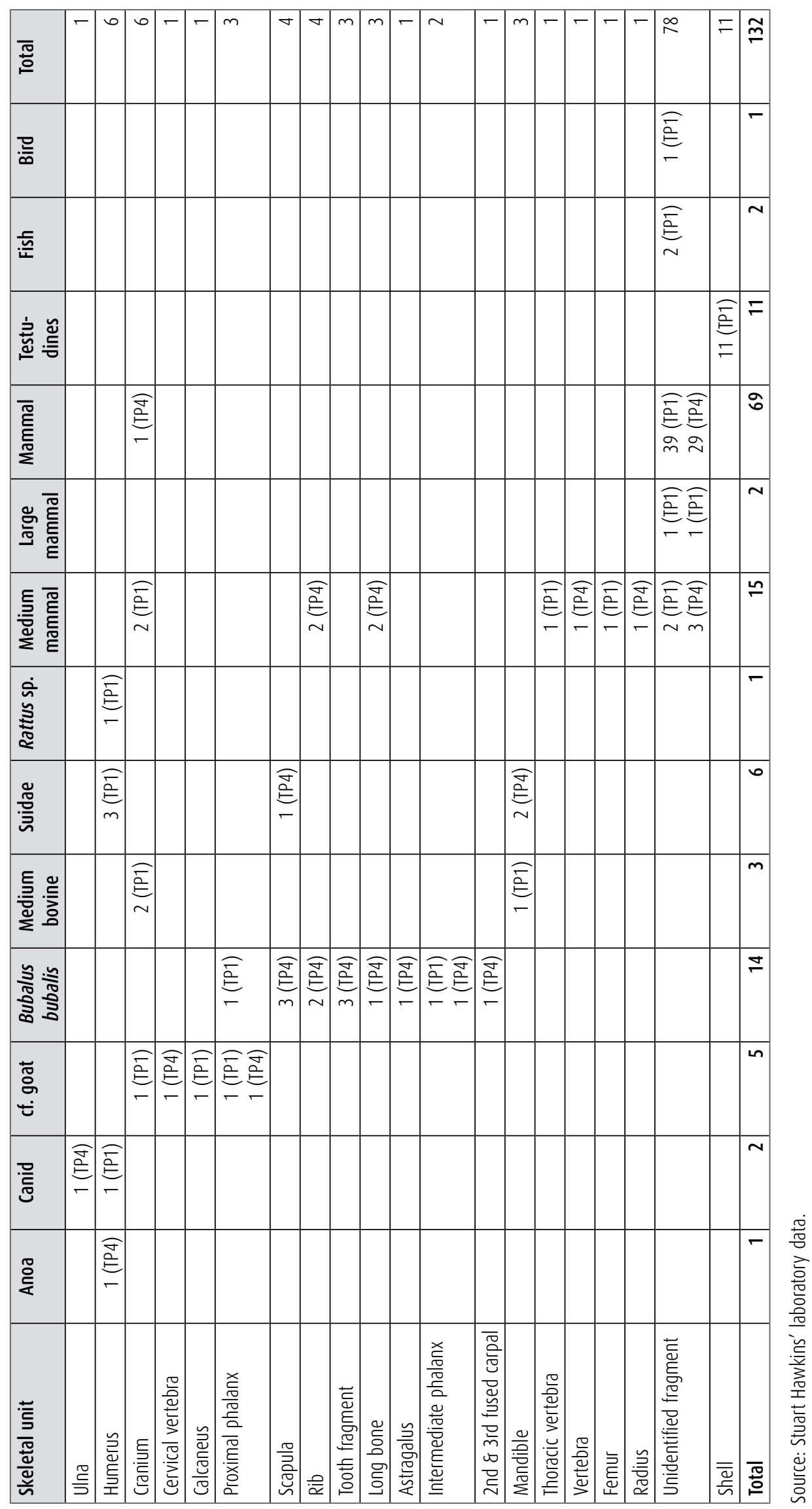


TP1 Spits 7-9 had concentrations of unidentified mammal bone fragments, while Spit 7 also had a concentration of turtle (Testudines) shell fragments. A single rat humerus was recovered from Spit 7. A water buffalo (Bubalus bubalis) proximal phalanx, a Canid (dog) humerus distal shaft fragment with four parallel cut marks, and a Suid (pig) humerus shaft were identified from Spit 9. A few unidentifiable fish bones were present in Spit 8, while an unidentified bird long bone shaft was present in Spit 9. The presence of turtle shell and fish remains restricted to TP1 Spits 7 and 8 suggests a marine component to the diet, in accord with the evidence for marine shellfish collection during the 13 th and 14 th centuries. However, it should be noted that the presumed turtle shell could have belonged to the Sulawesi forest turtle (Leucocephalon yuwonoi).

TP4 had concentrations of unidentified mammal bone fragments from Spit 4. A dog ulna fragment identified from Spit 3 has an oblique regular fracture and three parallel cut marks, indicating butchery for food or materials for manufacture. The dog remains from both TP1 and TP4 most likely belonged to the domesticated Canis familiaris. Pig remains (species unknown) were also identified from TP4, including a mandibular deciduous fourth premolar and a permanent mandibular incisor from Spit 4, as well as a partially carbonised scapula with a fused epiphysis from Spit 5. This indicates the remains of at least one pig sub-adult individual. These sparse Suid remains from TP1 and TP 4 could represent domestic pig Sus scrofa or wild pigs (Sulawesi warty pig (Sus celebensis) and Sulawesi babirusa (Babyrousa celebensis)). The endemic pygmy water buffalo or Anoa was identified on the basis of a distal shaft humerus fragment from Spit 3, which had been sawn with a sharp implement leaving parallel saw marks.

Common to both units TP1 and TP4 are a range of medium mammal and medium bovine fragments or cf. goat (Capra hircus). The cf. Capra hircus fragments were too fragmented to tell the difference between sheep and goat using known osteological markers (Boessneck 1969; Prummel and Frisch 1986), but it is likely they are goat Capra hircus fragments based on known mammal introductions into South Sulawesi. Some of the medium bovine fragments could also potentially be the introduced rusa deer (Cervus timorensis), which has thrived in South Sulawesi since its late Holocene introduction (Simons and Bulbeck 2004) and which the 18th-century chronicle of Wajo records as a mammal once abundant in the landscape:

Before there were people living in Wajo there were only wide expanses of grass, and thick, pathless forests that were home to animals: wild pigs, deer, buffaloes and birds. There were numerous lakes full of fish, as well as crocodiles (Zainal Abidin 1985:52).

The Anoa fragment in the assemblage can be positively matched with the lowland Bubalus depressicornis (Figure 17.4), although no comparative specimens of the mountain Bubalus quarlesi were available to rule out that possible identification. These two Anoa species are still present on Sulawesi in very small numbers, with the former confined to retreating forest margins and the latter to mountain ranges (Burton et al. 2005). The endemic buffalo presence in the assemblage probably represents hunting of the lowland Anoa Bubalus depressicornis within or on the fringes of extant rainforest that may have been present nearby, although whether early or late during Allangkanangnge's period of occupation is unknown owing to disturbance

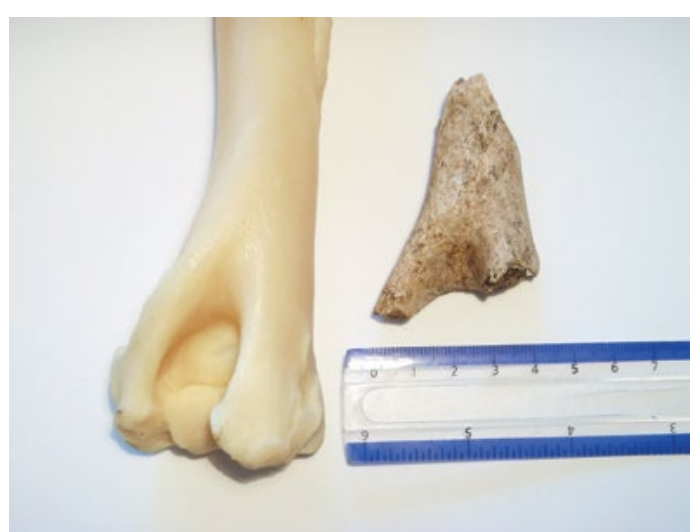

Figure 17.4: Dorsal humerus: comparison of Anoa specimen 1847-354 at left and the TP4 fragment at right.

Source: Anoa specimen courtesy Musée d'histoire naturelle, Paris; photograph by David Bulbeck. to the TP 4 deposit. 
Also, common to both excavation units are a number of large bovine remains, one each from TP1 Spits 8 and 9 and 12 from Spits 3 to 6 in TP4. These are undoubtedly water buffalo (Bubalus bubalis) remains as no other large bovines are known to have been introduced to Sulawesi before recent times (Simons and Bulbeck 2004). Water buffalo elements include mostly foot bones (astragalus, second and third fused carpal, intermediate phalanges), as well as ribs and scapula bones. Two of these scapula fragments from TP4 represent two water buffalo individuals with fused epiphyses, while the phalanges' proximal epiphyses were unfused suggesting at least one sub-adult individual present but no juveniles. Four of these large bovine bones from TP4 had a number of parallel cut marks and a long bone was split down the shaft in a fresh fracture (a sign that marrow was extracted).

In summary, the vertebrate identifications reflect a faunal assemblage dominated by domesticated (water buffalo, dog) or potentially domesticated (suid, cf. goat) taxa. The suid and cf. goat taxa can be characterised no more closely than potentially domesticated because, in the former case, an unknown proportion may represent the native Sulawesi warty hog and 'pig-deer' suids rather than the introduced, domesticated Sus scrofa pig, and, in the latter case, an unknown proportion may be the remains of deer (introduced to Sulawesi to roam wild) rather than goats. The suid and dog identifications reflect the pre-Islamic character of the vertebrate identifications as both of these are regarded as unclean beasts according to Islamic precepts. Equally importantly, cut marks on the bone fragments reveal a pattern of intensive butchery and meat consumption, which may well reflect feasting activities as would befit a palace centre. Also, water buffaloes are a critical traction animal for traditional wet-rice agriculture, which aligns with the evidence from micro-fossils in the sediment samples in indicating the major role of rice in the subsistence economy at Allangkanangnge (Bulbeck and Caldwell 2008).

\section{Plant remains}

Conditions for the preservation of plant material appear to have been far from ideal at Allangkanangnge. The recovered charcoal amounted to $287 \mathrm{~g}$ (and just $39 \mathrm{~g}$, if the suspected cremation burial from TP4 is excluded), and just two fragments of wood were preserved (Tables 17.1-17.4). The anaerobic conditions at Utti Batue, in contrast, fostered the preservation of $1.4 \mathrm{~kg}$ of charcoal, $13 \mathrm{~kg}$ of wood and around $1.7 \mathrm{~kg}$ of other plant matter in the excavated test pit. The large quantity of wood at Utti Batue can be attributed to timber houses erected on piles in the traditional Bugis manner (Bulbeck et al. 2007). This had surely occurred at Allangkanangnge too despite the lack of direct archaeological evidence (Bulbeck and Caldwell 2008), and probably involved the construction of a wooden palace on the hilltop summit.

The importance of plant micro-fossils at a site with poor plant-matter preservation, such as Allangkanangnge, is amply shown by the thousands of rice phytoliths identified within the TP1 deposits excavated in 1999. Each $5 \mathrm{~g}$ sample from Spits 1-6, which are dated to between the 14 th and 17 th centuries, yielded approximately 500-1700 rice phytoliths. While unidentifiable as originating from dryland rice or wetland rice, the phytoliths reflect the pounding and final winnowing of rice (Bulbeck and Caldwell 2008). However, the local area under cultivation was probably less extensive when Allangkanangnge was first occupied, with the possibility of primary forest within foraging range as suggested by the analysis of the vertebrate faunal remains described above, and the name of a nearby settlement, Sumpang Alek ('Mouth of the Forest'). 


\section{Discussion}

Zone 1 was selected for excavation because of its retention of stratified deposit, as well as its topographic prominence and the fact that it is bordered by a low stone wall, which appears to be original. However, the evidence for pre-Islamic burials in Zone 1 is weak. Only one of the four test pits (TP4) produced remains that can be reasonably attributed to a pre-Islamic cremation burial, and its direct dating suggests that a pre-16th-century interment is unlikely (Table 17.4). Similarly, prestige goods take a clear second place to quotidian items in the excavated remains, as reflected in the ratio of one tradeware sherd to 120 earthenware sherds, and the absence of gold and scarcity of bronze. Zone 1 may have been the site of a wooden palace and a focus for feasting and related ceremonial activities, consistent with the vertebrate assemblage, rice phytoliths and earthenware assemblage dominated by serving vessels and cooking pots. A change to its predominant use for burials can be dated to the 16th or even the 17th century.

The purpose of the numerous stone arrangements with a central standing stone is not known, but it is possible that they mark the burials of cremated remains in jars (Bulbeck et al., this volume). The concentration of these structures along the southern ridge, where there is a high proportion of martavan sherdage similar to the hilltop, and their further dispersal onto the eastern slopes would go some way to explaining the distribution of imported ceramics over the site.

Both the excavated remains and the surface tradeware collection agree in dating initial settlement of Allangkanangnge to the 13th century, followed by a major occupation phase between the 14th and 16th centuries. The major attraction of the site during the 13th and 14th centuries may have been its status as a raised location closer than it is today to the mouth of the Cenrana River, from where trade could be controlled and taxed. With the subsequent progradation of the lower Cenrana, the opportunities for wet-rice cultivation in the vicinity of the site would have improved, and an emphasis on farming rather than a coastal economy evidently underpinned the site's 14 th-16th-century heyday.

In the lead-up phase, during the 13th and 14th centuries, estuarine and coastal conditions apparently lay within the foraging range of the Allangkanangnge inhabitants, as reflected by the excavated shellfish dating to this period as well as the fish and turtle remains from TP1 Spits 7 and 8. This observation implies marked progradation of the lower Cenrana following the 14th century and, following the geomorphological model of Carson (2017), a dramatic expansion of the flanking lands suitable for wet-rice production. The central lakes area, of which Allangkanangnge forms part, is an ideal region in which to develop irrigated wet-rice cultivation due to seasonal inundation. The margins of the lakes and swamps that characterise the landscape form natural rice beds; today, one can witness the speculative planting of wetland rice on the margins of Lake Tempe. The management of these lake edges tends naturally to the construction of artificial bunds and the development of drainage, as well as co-operative forms of hydrological management (Caldwell and Lillie 2004).

Allangkanangnge would have been an ideal place from which to direct the expansion of agrarian settlement and expansion south and east of Lake Tempe during the 15th and 16th centuries. Whoever occupied the hill during this period would have almost certainly have taken a close interest in the central direction of wet-rice cultivation. Analogously, the 'Chronicle of Bone' describes the process of agrarian expansion during the 15th century within a pocket of coastal plain to the south of the Cenrana before extending its zone of direct influence as far north as the Cenrana during the 16th century (Macknight 1983). 
It is difficult to directly match Allangkanangnge, which was continuously occupied from the 13th to late 17 th centuries, with a kingdom called Cina that originated in the Cenrana Valley to the east in the 13th century, rose to prominence in the 14th and 15th centuries, and vanished in the 16 th century. Cina appears to have had more than one palace site; indeed, it is difficult to identify any fixed centre in the historical record of Cina (Caldwell and Wellen 2017). The local tradition that Allangkanangnge was the pre-eminent palace site of Cina cannot be proven by archaeology, nor by historical sources as these do not name it. Certainly, however, Allangkanangnge's location, the richness of the ceramic assemblages on its hilltop, the evidence for elite feasting from the vertebrate identifications, and the persistent oral tradition that the hill was once the palace site of Cina, point to its being the focus of an important polity in the central lakes region.

\section{Conclusion}

Survey and excavation of the Allangkanangnge site document light occupation during the 13th century and a more intense phase of occupation between the 14th and 16th centuries. Faunal remains reflect a minor marine component to the diet from initial occupation through to the 14th century. Wet-rice cultivation probably underpinned the subsistence economy throughout the period of occupation although direct evidence for this relates to the 14th century onwards. The large assemblage of excavated earthenware pottery reflects a range of domestic activities including storage and food preparation and serving, as well as iron metallurgy (which is also recorded in local folklore for the site). At the height of its prosperity, the settlement evidently consisted of a major building or palace centre on the summit and rectangular stone arrangements marking the burial sites of cremated remains in jars along the southern ridge and eastern slopes. During the 17th century, occupation declined and there was a greater emphasis on mortuary activities. The site was probably abandoned in 1670 as a result of the harrowing of Wajo by Arung Palakka La Tenritatta (Andaya 1981).

In a landmark paper, Macknight (1983) suggested a date of around AD 1400 for the start of this agrarian expansion, based on the evidence of the Bugis chronicle of the kingdom of Bone, but in later publications this estimate has been revised down to $\mathrm{AD}$ 1300, based on new data (Bulbeck and Caldwell 2000; Druce 2009). In this paper, we establish that origins of the agrarian expansion lay in the 13th century, and that the process of centralised expansion of wet-rice agriculture, which today dominates the landscape of lowland South Sulawesi, may have begun in the western Cenrana valley. The complementary economic specialisations of South Sulawesi's late pre-Islamic economy-Luwu's production of ironware for local use and trade (Bulbeck and Caldwell 2000), intensive wet-rice production in the lower Walennae and Cenrana valleys (this paper), and longdistance maritime trade along the south coast (Nayati 2005)—can be confidently traced back to the 13 th/14th centuries.

\section{Acknowledgements}

The Australian Research Council funded the 1999 fieldwork at the Allangkanangngne site and paid for one of the radiocarbon dates, while the British Academy funded the 2005 fieldwork season. The Centre for Archaeological Research (The Australian National University) funded two radiocarbon dates and the University of Hull paid for one radiocarbon date. The laboratory work on the surveyed and excavated remains was funded by the Australia-Indonesia Institute. The comments from two anonymous referees on an earlier version of this paper are gratefully acknowledged. 


\section{Author biographies}

Budianto Hakim Makassar Archaeology Office, Makassar, South Sulawesi, Indonesia

Stuart Hawkins Department of Archaeology and Natural History, School of Culture, History and Language, College of Asia and the Pacific, The Australian National University, Canberra, Australia

David Bulbeck Department of Archaeology and Natural History, School of Culture, History and Language, College of Asia and the Pacific, The Australian National University, Canberra, Australia

Ian Caldwell Archaeological Studies Program, University of the Philippines Diliman, Republic of the Philippines

Stephen Druce Academy of Brunei Studies, Universiti Brunei Darussalam, Brunei Darussalam Campbell Macknight College of Asia and the Pacific, The Australian National University, Canberra, Australia

\section{References}

Adhyatman, S. and R. Arifin. 1996. Manik-Manik di Indonesia Beads in Indonesia. 2nd edition. Jakarta: Penerbit Djambatan.

Andaya, L.Y. 1981. The Heritage of Arung Palakka: A History of South Sulawesi (Celebes) in the Seventeenth Century. Verhandelingen van het Koninklijk Instituut voor Taal-, Land- en Volkenkunde 91. The Hague: Martinus Nijhoff.

Beck, H. 1936. Beads \& Magic. London: Robert Stockwell.

Boessneck, J. 1969. Osteological differences between sheep (Ovis aries Linné) and goat (Capra hircus Linné). In D.R. Brothwell and E.S. Higgs (eds), Science in Archaeology: A Survey of Progress and Research. London: Thames and Hudson.

Bronk Ramsey, C. 2013. OxCal 4.2 manual. c14.arch.ox.ac.uk/oxcal/OxCal.html (accessed 27 October 2018).

Bulbeck, F.D. 1992. A Tale of Two Kingdoms: The Historical Archaeology of Gowa and Tallok, South Sulawesi, Indonesia. Unpublished PhD thesis, School of Archaeology and Anthropology, The Australian National University, Canberra. Available at www.oxis.org/theses/bulbeck-1992.pdf (accessed 5 June 2018).

Bulbeck, D. 2000. Sediments and Ceramics from Cina and Cenrana. Report to the Australia-Indonesia Institute, Appendix A. Canberra: The Australian National University.

Bulbeck, D. 2009. The application of Darwinian cultural evolutionary theory to ceramics: the case of 'soft pottery' from Luwu, South Sulawesi, Indonesia. In H.J. Muscio and G.E.J. López (eds), Theoretical and Methodological Issues in Evolutionary Archaeology: Toward an Unified Darwinian Paradigm Questions théorétiqes et méthodologiques en archéologie évolutive: Vers un paradigme Darwinien unifié, pp. 3-11. Oxford: BAR International Series 1915.

Bulbeck, D., F.A. Aziz, S. O’Connor, A. Calo, J.N. Fenner, B. Marwick, J. Feathers, R. Wood and D. Prastiningtyas. 2016. Mortuary caves and the dammar trade in the Towuti-Routa region, Sulawesi, in an Island Southeast Asian context. Asian Perspectives 55(2):148-183. doi.org/10.1353/asi.2016.0017 (accessed 5 June 2018). 
Bulbeck, D., D. Bowdery, J. Field and B. Prasetyo. 2007. The Palace Centre of Sago City: Utti Batue site, Luwu, South Sulawesi, Indonesia. In M. Lillie and S. Ellis (eds), Wetland Archaeology \& Environments: Regional Issues, Global Perspectives, pp. 119-141. Oxford: Oxbow Books.

Bulbeck, D. and I. Caldwell. 2000. Land of Iron: The Historical Archaeology of Luwu and the Cenrana Valley. Results of the Origin of Complex Society in South Sulawesi Project (OXIS). Hull: Centre for South-East Asian Studies, University of Hull. Available at www.oxis.org/books/land-of-iron.pdf (accessed 5 June 2018).

Bulbeck, D. and I. Caldwell. 2008. Oryza sativa and the origins of kingdoms in South Sulawesi, Indonesia: Evidence from rice husk phytoliths. Indonesia and the Malay World 36(104):1-20. doi.org/10.1080/ 13639810802016117 (accessed 5 June 2018).

Bulbeck, D., I. Caldwell, S. Druce, B. Hakim and C. Macknight. 2018. Imported tradeware ceramics and their relevance for dating socio-political developments in South Sulawesi, with special reference to the Allangkanangnge ri Latanete site. In S. O'Connor, D. Bulbeck and J. Meyer (eds), The Archaeology of Sulawesi: Current Research on the Pleistocene to the Historic Period, pp. 269-286. Canberra: ANU Press.

Bulbeck, D. and B. Prasetyo. 2000. Perkembangan masyarakat di Sulawesi Selatan: Hasil penelitian sementara di Luwu. In M.A. Fadillah and I. Sumantri (eds), Kedatuan Luwu: Perspektif Arkeologi, Sejarah dan Antropologi, pp. 29-46. Makassar: Lembaga Penerbitan Universitas Hasanuddin/Institut Etnografi Indonesia.

Burton, J.A., S. Hedges and A.H. Mustari. 2005. The taxonomic status, distribution and conservation of the lowland anoa Bubalus depressicornis and mountain anoa Bubalus quarlesi. Mammal Review 35(1):25-50. doi.org/10.1111/j.1365-2907.2005.00048.x (accessed 5 June 2018).

Caldwell, I. 1988. South Sulawesi A.D. 1300-1600: Ten Bugis Texts. Unpublished PhD thesis, Department of History, The Australian National University, Canberra. www.oxis.org/theses/caldwell-1988.pdf (accessed 5 June 2018).

Caldwell, I. 1995. Power, state and society among the pre-Islamic Bugis. Bijdragen tot de Taal-, Land-en Volkenkunde 151(3):394-421. doi.org/10.1163/22134379-90003038 (accessed 5 June 2018).

Caldwell, I. and M. Lillie. 2004. Manuel Pinto's inland sea: Using palaeoenvironmental techniques to assess historical evidence from southwest Sulawesi. In S.G. Keates and J.M. Pasveer (eds), Modern Quaternary Research in Indonesia, pp. 259-271. Quaternary Research in Southeast Asia, Volume 18. Leiden: A.A. Balkema.

Caldwell, I. and K. Wellen. 2016. Family matters: Bugis genealogies and their contribution to Austronesian studies. In S.C. Druce (ed.), Orality, Writing and History: The Literature of the Bugis and Makasar of South Sulawesi. International Journal of Asia Pacific Studies 12(Supplement 1): 119-141. doi.org/10.21315/ ijaps2016.12.s1.6.

Caldwell, I. and K. Wellen. 2017. Finding Cina: A new paradigm for early Bugis history. Bijdragen tot de Taal-, Land-en Volkenkunde 173(2/3):296-324. doi.org/10.1163/22134379-17302004 (accessed 5 June 2018).

Carson, M. 2017. Coastal palaeo-landscapes of the Neolithic. Invited contribution to P. Bellwood, First Islanders: Prehistory and Human Migration in Island Southeast Asia, pp. 240-244. Oxford: Wiley Blackwell.

Clune, G. and D. Bulbeck. 1999. Description and preliminary chronology of Macassar historical earthenware decorations. Walennae 3(2):39-60. doi.org/10.24832/wln.v2i1.65 (accessed 5 June 2018).

Do, M. 2013. Iron-Nickel Alloy Smelting Production in Luwu, South Sulawesi during the pre-Islamic Period. Unpublished MSc thesis, Institute of Archaeology, University College London, London. www. oxis.org/theses/misol-2103.pdf. 
Druce, S.C. 2009. The Lands West of the Lakes: A History of the Ajattappareng Kingdoms of South Sulawesi, 1200 to $1600 \mathrm{CE}$. Leiden: Verhandelingen van het Koninklijk Instituut voor Taal-, Land- en Volkenkunde 261. doi.org/10.1163/9789004253827 (accessed 5 June 2018).

Druce, S., D. Bulbeck and I. Mahmud. 2005. A transitional Islamic Bugis cremation in Bulubangi, South Sulawesi: Its historical and archaeological context. Review of Indonesian and Malaysian Affairs 39(1):1-22.

Fadillah, M.A. and I. Sumantri (eds). 2000. Kedatuan Luwu: Perspektif Arkeologi, Sejarah dan Antropologi. Makassar: Lembaga Penerbitan Universitas Hasanuddin/Institut Etnografi Indonesia.

Gremmen, W.H.E. 1990. Palynological investigations in the Danau Tempe depression, southwest Sulawesi (Celebes), Indonesia. Modern Quaternary Research in Southeast Asia, pp. 123-134. Quaternary Research in Southeast Asia, Volume 11. Rotterdam: A.A. Balkema.

Macknight, C.C. 1983. The rise of agriculture in South Sulawesi before 1600. Review of Indonesian and Malaysian Affairs 17:92-116.

Macknight, C.C. and P. Mukhlis. n.d. The Chronicle of Bone. Unpublished typescript.

Miksic, J.N. and C.T. Yap. 1990. X-ray fuorescence data on earthenware pottery trade in Sumatra, 12th-14th centuries. Paper presented at the 14th Indo-Pacific Prehistory Association Congress, Yogyakarta, 25 August - 2 September.

Morales Muniz, A. 1988. On the use of butchering as a paleocultural index: Proposal of a new methodology for the study of bone fracture from archaeological sites. ArchaeoZoologia 2(1/2):111-150.

Nayati, W. 2005. Social Dynamics and Local Trading Patterns in the Bantaeng Region, South Sulawesi (Indonesia) circa 17th Century. Unpublished PhD thesis, The Southeast Asian Studies Programme, National University of Singapore, Singapore. www.oxis.org/theses/widiya-nayati-2005.pdf (accessed 5 June 2018).

Nurhayati, R., A. Hukma and I. Anwar (eds). 2003. La Galigo: Menelusuri jejak Warisan Sastra Dunia. Makassar: Pusat Studi La Galigo, Hasanuddin University.

Pelras, C. 1996. The Bugis. Oxford: Basil Blackwell.

Pelras, C. 2010. Explorations dans l'univers des Bugis: Un choix de trente-trois rencontres. Cahiers d'Archipel 39. Paris: Association Archipel.

Prummel, W. and H.-J. Frisch. 1986. A guide for the distinction of species, sex and body side in bones of sheep and goat. Journal of Archaeological Science 13(6):567-577. doi.org/10.1016/0305-4403(86) 90041-5 (accessed 5 June 2018).

Sadek-Kooros, H. 1975. Intentional fracturing of bone: Description of criteria. In A.T. Clason (ed.), Archaeozoological Studies, pp. 139-150. Amsterdam: North Holland Publishing Co.

Schmid, E. 1972. Atlas of Animal Bones: For Prehistorians, Archaeologists and Quaternary Geologists. Amsterdam: Elsevier Science Publishers.

Shipman, P., W. Bosler, K.L. Davis, A.K. Behrensmeyer, R.I.M. Dunbar, C.P. Groves, F. Thackeray, J.A.H.V. Couvering and R.K. Stucky. 1981. Butchering of Giant Geladas at an Acheulian Site. Current Anthropology 22(3):257-268. doi.org/10.1086/202663 (accessed 5 June 2018).

Silver, I.A. 1969. The ageing of domestic animals. In D.R. Brothwell and E.S. Higgs (eds), Science in Archaeology: A Survey of Progress and Research, pp. 283-302. London: Thames and Hudson.

Simons, A.G. and D. Bulbeck. 2004. Late Quaternary faunal successions in South Sulawesi, Indonesia. In S.G. Keates and J.M. Pasveer (eds), Quaternary Research in Indonesia, pp. 167-189. Modern Quaternary Research in Southeast Asia, Volume 18. Leiden: A.A. Balkema. 
Stargardt, J. 2003. Mapping the mind: Some cultural cargoes of the sea-trade in Southeast Asia, 5th-13th centuries. In A. Karlström and A. Källén (eds), Fishbones and Glittering Emblems: Southeast Asian Archaeology 2002, pp. 103-117. Stockholm: Museum of Far Eastern Antiquities.

Sukamto, R. 1975. Peta Geologi Indonesia, Lembang Ujung Pandang, Benteng dan Sinjai. Bandung: Geological Research and Development Centre.

Tim Penyusun Laporan Ekskavasi Penyelamatan dan Rekonstruksi Dinding Barat BSO (Tim). 1992. Ekskavasi Penyelamatan dan Rekonstruksi Dinding Barat Benteng Somba Opu Kabupaten Gowa 14 September S.D 14 Nopember 1992. Makassar: Suaka Peninggalan Sejarah dan Purbakala Sulawesi Selatan dan Tenggara/Proyek Persiapan Pembangunan Miniatur Sulawesi Pemda Tingkat I Propinsi Sulawesi Selatan.

Wilson, B., C. Grigson and S. Payne (eds). 1982. Ageing and Sexing Animal Bones from Archaeological Sites. British Archaeological Reports British Series 109. Oxford: BAR Publishing.

Zainal Abidin, A. 1983. The emergence of early kingdoms in Sulawesi. In A. Zainal Abidin (ed.), Persepsi Orang Bugis, Makasar tentang Hukum, Negara dan Dunia Luar, pp. 455-491. Bandung: Penerbit Alumni.

Zainal Abidin, A. 1985. Wajo' pada Abad XV-XVI: Suatu Penggalian Sejarah terpendam Sulawesi Selatan dari Lontara'. Bandung: Penerbit Alumni. 
This text is taken from The Archaeology of Sulawesi: Current Research on the Pleistocene to the Historic Period, edited by Sue O'Connor, David Bulbeck and Juliet Meyer, published 2018 by ANU Press, The Australian National University, Canberra, Australia.

doi.org/10.22459/TA48.11.2018.17 